\title{
Evaluation of rumen-protected methionine sources and period length on performance of lactating dairy cows within Latin squares ${ }^{1}$
}

\author{
B. C. Benefield, ${ }^{*}$ R. A. Patton, $\dagger$ M. J. Stevenson, $\ddagger^{2}$ and T. R. Overton ${ }^{* 3}$ \\ *Department of Animal Science, Cornell University, Ithaca, NY 14853 \\ †Nittany Dairy Nutrition Inc., Mifflinburg, PA 17844 \\ łEvonik-Degussa Corporation, Kennesaw, GA 30144
}

\begin{abstract}
Multiparous Holstein cows $(\mathrm{n}=16)$ were used in a replicated $(\mathrm{n}=4)$ Latin square design with 2 -wk periods to determine whether length of the experimental period chosen within Latin square designs would influence experimental outcomes for performance-related variables. Cows were fed a basal TMR formulated to supply Lys in excess of the predicted requirements and either no rumen-protected Met (RP-Met; control), or 6 (M6) or 12 (M12) g/d of RP-Met (Mepron), or 12 (S12) g/d of RP-Met (Smartamine M). Performance outcomes were evaluated separately using data collected at the end of each week of each period, and as overall means for each period. Milk yield was not affected by treatment in any period. Supplementation of RP-Met from all sources tended to increase milk fat percentage when evaluated using wk-1 data, but responses evaluated using wk-2 data only were not significant. Supplementation of M12 and S12 tended to increase milk fat percentage over the entire experimental period. Supplementation of M6 and M12 tended to increase milk true protein percentage when evaluated using wk-1 data only; however, responses to treatments during wk 2 were not significant. All supplemental RP-Met treatments either tended to increase (M6 and S12) or increased (M12) milk true protein content over the entire experimental period relative to the control treatment. Yields of fat and true protein were not affected by treatment. Carryover effects of treatment on production variables were largely not significant. Predictions of nutrient supply with 3 models used in dairy ration formulation and evaluation (CPM-Dairy, AminoCow, and 2001 NRC Dairy) indicated that energy, protein, and Met all were supplied in excess of requirements for all treatments. Overall, results suggest that interpretation of perfor-
\end{abstract}

\footnotetext{
Received April 16, 2008.

Accepted April 17, 2009. GA.

${ }^{1}$ Supported in part by Evonik-Degussa Corporation, Kennesaw,

${ }^{2}$ Current address: Halchemix Canada Inc., Uxbridge, Ontario L9P 1H3, Canada.

${ }^{3}$ Corresponding author: tro2@cornell.edu
}

mance outcomes can vary depending on selection of the experimental period in Latin squares, and responses to increased Met supply based on ratio-based formulation may not be independent of the grams of Met supplied. Key words: dairy cow, milk protein, methionine

\section{INTRODUCTION}

Nutritional strategies to increase the yield and content of protein in milk from lactating dairy cows continue to be of substantial economic interest to the dairy industry. Most of the focus in research and industry applications has been directed toward increasing the absorbable and net splanchnic supplies of Met and Lys as the 2 limiting AA in most dietary situations (reviewed by NRC, 2001; Doepel et al., 2004; Lapierre et al., 2006). Although feedstuff-based sources (various treated soybean meal sources and blood meal with high degrees of ruminal undegradability) are readily available to increase the supply of absorbable Lys in diets fed to dairy cows, the most efficient approach to increase the supply of absorbable Met to dairy cows is to include a rumen-protected Met (RP-Met) source in the diet. Among the commercially available RP-Met sources, both Mepron (Evonik-Degussa Corporation, Kennesaw, GA) and Smartamine M (Adisseo USA Inc., Alpharetta, GA) have been demonstrated to have a high degree of ruminal protection and also a high degree of postruminal bioavailability (Papas et al., 1984; Overton et al., 1996). Increasing the dietary supply of Met by using Mepron also has been demonstrated to increase the net splanchnic release of Met for use by mammary and other tissues (Berthiaume et al., 2006).

The majority of the experiments in which performance responses of lactating cows to AA supplementation, investigated either through postruminal infusion or dietary addition of a rumen-protected source, have been conducted using Latin square designs with relatively short (14 d or less) period lengths. Data from a previous study (Bucholtz et al., 2006) suggested that carryover effects on production parameters may exist when performance responses to AA supplementation are evaluated using Latin square designs. Therefore, it 
was of interest to determine whether the length of experimental period chosen within a Latin square design would influence the experimental outcomes in terms of the performance variables studied.

In addition to evaluating the potential for carryover effects of dietary addition of RP-Met sources within Latin square designs, it was of interest to generate additional data to compare performance predictions from models commonly used in the dairy industry to evaluate AA nutrition of lactating dairy cows [CPM-Dairy version 3.0 from University of Pennsylvania, Miner Institute, and Cornell University; AminoCow from Evonik-Degussa Corporation; and the NRC (2001) Dairy model]. The NRC (2001) Dairy model uses a ratio-based approach to evaluate supplies of digestible Met and Lys, each expressed as a percentage of MP supply. Assuming adequate Lys, this model predicts linear increases in milk protein content and yield as digestible Met is increased from 1.80 to approximately $2.40 \%$ of MP, and then a plateau in response thereafter. A similar system is incorporated within CPM-Dairy. AminoCow and CPM-Dairy also have factorial systems to evaluate AA supply and requirements. Few studies are available that compare performance predictions using these 2 types of AA evaluation systems.

The first objective of this experiment was to evaluate the performance responses of lactating dairy cows to dietary supplementation with 2 commonly used commercial sources of RP-Met. The second objective was to determine whether length of the study period within Latin square designs would affect productive response variables, interpretation of experimental results, and the presence or absence of carryover effects on productive performance. Finally, a third objective was to compare predictions of Met supply with productive outcomes using commercially available nutrition models with AA evaluation systems.

\section{MATERIALS AND METHODS}

\section{Cows, Experimental Design, and Treatments}

The Cornell University Institutional Animal Care and Use Committee approved all procedures involving animals in this study, and the experiment commenced in February 2005 and ended in April 2005. Multiparous Holstein cows $(\mathrm{n}=16)$ from the Cornell University Teaching and Research Center dairy herd were assigned to 1 of 4 dietary treatments in a replicated $(\mathrm{n}=4)$ Latin square design with 14 -d periods. At the onset of the experiment, cows averaged $42.2 \pm 2.7 \mathrm{~kg} / \mathrm{d}$ of milk and were $139 \pm 16$ DIM. Cows were assigned to squares in blocks according to preexperimental milk yield, and squares were balanced to allow for determination of carryover effects. All cows were fed a basal diet as TMR that was formulated to supply Lys in excess of predicted requirements (regardless of the AA evaluation system used) and was not supplemented with RP-Met (Table 1). Treatments consisted of 0 (control), $6 \mathrm{~g} / \mathrm{d}$ of RP-Met as Mepron (M6), $12 \mathrm{~g} / \mathrm{d}$ of RP-Met as Mepron (M12), and $12 \mathrm{~g} / \mathrm{d}$ of RP-Met as Smartamine M (S12). Further information on protection schemes and Met delivery from the sources used is available from Overton et al. (1996) for Mepron and Papas et al. (1984) for Smartamine M. The daily treatment for each cow was mixed into $0.45 \mathrm{~kg}$ of wheat middlings and combined with the basal TMR at the mixer. All cows were housed in individual tie stalls and were milked 3 times per day throughout the experiment.

\section{Sample Collection and Analyses}

Milk yields were measured at each milking, and samples were collected from each cow at each milking during the last $2 \mathrm{~d}$ of each week. Individual milk samples were analyzed for content of fat, true protein, lactose, TS, MUN, and SCC by midinfrared spectroscopy (DairyOne Cooperative, Ithaca, NY) using AOAC (2000) methods as described by Smith et al. (2007).

Amounts of feed offered and refused were measured on a daily basis, and samples of the forage components, concentrate mixture, and TMR were collected on a weekly basis and dried at $55^{\circ} \mathrm{C}$ until static weight was reached for measurement of DM content. Daily DMI were calculated for each cow using the respective amounts of feed consumed and the appropriate weekly DM content of the TMR. Samples of individual forage components and the concentrate mixture were submitted at the end of each period to Cumberland Valley Analytical Services (Maugansville, MD) for analysis using wet chemistry techniques for CP (AOAC, 2000), acid detergent insoluble $\mathrm{CP}[\mathrm{CP}$ determined using AOAC (2000) after acid detergent extraction (AOAC, 2000)], neutral detergent insoluble CP [AOAC (2000) method for CP after neutral detergent extraction (Van Soest et al., 1991)], soluble CP, (Krishnamoorthy et al., 1982), ADF (AOAC, 2000), NDF (AOAC, 2000), lignin (Goering and Van Soest, 1970), starch (Holm et al., 1986), sugar (Dubois et al., 1956), ether extract (AOAC, 2000), and ash (AOAC, 2000). Chemical composition of the basal TMR based on the composition of the components is reported in Table 1.

Body weight of each cow was measured on 2 consecutive days before initiation of treatments and at the end of each period and BW were averaged before statistical analysis. Body condition scores were assigned to individual cows before assignment to treatment and at the end of each 2 -wk period, using a 5 -point scale $(1=$ thin to $5=$ obese; Wildman et al., 1982). 


\section{Statistical Analyses}

Data for DMI, milk yield, and milk composition were subjected to ANOVA for a replicated Latin square design using the GLM procedure (SAS Institute, 2001). Terms in the model included square, period(square), cow(square), treatment, and the interaction of treatment and square. Statistical analyses were conducted separately for data collected at the end of wk 1 and 2 of each period and for the average of these data. Data for BW and BCS collected at the end of each 2-wk period were analyzed with the same model used to analyze other variables. Means were separated using the PDIFF option with Tukey's adjustment within SAS. Carryover effects were assessed using the GLM procedure (SAS Institute, 2001) as contrasts of residuals as described by Gill (1978) for wk 1 and 2 of each period and for the average of these data. Significance was declared at $P<0.05$ and trends toward a significant difference at $0.05<P<0.15$. Least squares means are presented throughout.

\section{RESULTS}

Effects of RP-Met supplementation on milk yield and composition are presented in Table 2. Results are reported as analyzed separately using the data collected only at the end of wk 1 of each period, using the data collected only at the end of wk 2 of each period, and using the overall mean for data collected during each period. Dry matter intake tended $(P<0.08)$ to be increased in cows fed S12 compared with control cows during the first week of each period (29.2 vs. 28.4 $\mathrm{kg} / \mathrm{d}$ ); however, differences among treatments were not significant when analyzed using the data collected at the end of wk 2 or the overall period means.

Milk yield averaged $37.0 \mathrm{~kg}$ across the experiment, and differences between treatments were not significant. Milk fat percentage tended $(P<0.10)$ to be increased by all RP-Met treatments compared with the control treatment during wk 1, but differences among treatments were not significant when assessed using only the data collected at the end of wk 2 . When differences were assessed using overall period means, cows fed M12 and S12 tended $(P<0.11)$ to have increased milk fat content compared with control cows. Differences in milk fat yield were not significant at the end of wk 1 , at the end of wk 2, or as overall means. Similar to the patterns of response for milk fat percentage, milk true protein percentage tended $(P<0.13)$ to be increased for cows fed M6 (3.02\%) and M12 (3.02\%) compared with control cows $(2.90 \%)$ during wk 1, but differences among treatments when assessed at the end of wk 2 were not significant. When data were analyzed using
Table 1. Ingredient and chemical composition of the basal TMR

\begin{tabular}{lc}
\hline Item & Amount, \% of DM \\
\hline Ingredient $^{1}$ & \\
Corn silage $^{2}$ & 37.3 \\
Alfalfa hay $^{2}$ & 19.9 \\
Ground shelled corn, finely ground $^{\text {Soybean meal, 47.5\% CP, solvent extracted }}$ & 13.6 \\
Soybean hulls, pelleted $^{3}$ & 7.94 \\
SoyPlus $^{3}$ & 6.02 \\
Wheat middlings & 5.90 \\
Cane molasses & 4.01 \\
Sodium bicarbonate & 2.21 \\
Calcium carbonate & 1.20 \\
Salt & 0.80 \\
Calcium sulfate & 0.44 \\
Dicalcium phosphate & 0.20 \\
Urea, 281\% CP & 0.18 \\
Magnesium oxide & 0.10 \\
Mineral and vitamin mix ${ }^{4}$ & 0.06 \\
Chemical composition & 0.20 \\
CP & \\
Acid detergent insoluble CP & 16.4 \\
Neutral detergent insoluble CP & 0.9 \\
Soluble CP & 2.2 \\
NDF & 6.4 \\
ADF & 32.8 \\
Lignin & 20.4 \\
NFC & 3.6 \\
Starch & 42.4 \\
Sugar & 24.0 \\
Ether extract & 5.5 \\
Ash & 3.0 \\
\hline & 7.6 \\
\hline Coint & \\
\hline
\end{tabular}

${ }^{1}$ Contained $7.44 \% \mathrm{CP}, 4.46 \%$ soluble $\mathrm{CP}, 0.64 \%$ acid detergent insoluble CP, $0.96 \%$ neutral detergent insoluble CP, $39.0 \%$ NDF, $22.7 \%$ ADF, $2.7 \%$ lignin, $3.3 \%$ ash, $2.9 \%$ ether extract, $0.9 \%$ sugar, and $34.8 \%$ starch.

${ }^{2}$ Contained $18.0 \% \mathrm{CP}, 6.48 \%$ soluble $\mathrm{CP}, 1.40 \%$ acid detergent insoluble CP, $2.54 \%$ neutral detergent insoluble CP, $42.4 \% \mathrm{NDF}, 34.2 \%$ ADF, $8.0 \%$ lignin, $9.6 \%$ ash, $2.4 \%$ ether extract, $6.7 \%$ sugar, and $2.3 \%$ starch.

${ }^{3}$ West Central Soy (Ralston, IA).

${ }^{4}$ Contained $3.0 \% \mathrm{Ca}, 25.0 \% \mathrm{Mg}, 6 \% \mathrm{~K}, 8.6 \% \mathrm{~S}, 8,600 \mathrm{mg} / \mathrm{kg}$ of $\mathrm{Fe}$, $18,600 \mathrm{mg} / \mathrm{kg}$ of Zn, $6,000 \mathrm{mg} / \mathrm{kg}$ of Cu, $16,000 \mathrm{mg} / \mathrm{kg}$ of Mn, $110 \mathrm{mg} /$ $\mathrm{kg}$ of Se, $330 \mathrm{mg} / \mathrm{kg}$ of Co, $570 \mathrm{mg} / \mathrm{kg}$ of I, 3,022 kIU/ $\mathrm{kg}$ of vitamin A, $1,027 \mathrm{kIU} / \mathrm{kg}$ of vitamin D, and 20,264 IU $/ \mathrm{kg}$ of vitamin E.

${ }^{5}$ Calculated as $100-[(\mathrm{NDF}-\mathrm{NDF} \mathrm{CP})+\mathrm{NDF}+\mathrm{CP}+$ ether extract]; NRC (2001).

overall period means, cows fed S12 (3.01\%) and M6 $(3.00 \%)$ tended $(P<0.13)$ to have increased milk true protein percentage and cows fed M12 $(3.03 \%)$ had increased milk true protein percentage $(3.03 \%)$ compared with control cows $(2.94 \% ; P<0.05)$. Despite these differences in milk true protein percentage, differences in milk true protein yield were not significant.

Lactose percentages and yields (Table 2) were not affected by treatment, except for a trend $(P<0.14)$ for a slight difference in lactose percentage between cows fed M12 and M6 during wk 2 (4.58 vs. 4.50\%). Whether this has any biological significance is unclear. Consistent with the patterns of response of milk fat percentage and milk true protein percentage to RP-Met 
Table 2. Least squares means for yield and composition of milk for cows fed a control diet or diets supplemented with $6 \mathrm{~g} / \mathrm{d}$ of rumen-protected Met (RP-Met) from Mepron (M6), $12 \mathrm{~g} / \mathrm{d}$ from Mepron (M12), or $12 \mathrm{~g} / \mathrm{d}$ of RP-Met from Smartamine M (S12) ${ }^{1}$

\begin{tabular}{|c|c|c|c|c|c|c|c|}
\hline Item & $\begin{array}{l}\text { Week } \\
\text { of period }\end{array}$ & \multicolumn{4}{|c|}{ Treatment } & $\mathrm{SE}$ & $P$-value for means separation using Tukey adjustment \\
\hline \multirow[t]{3}{*}{$\mathrm{DMI}, \mathrm{kg} / \mathrm{d}$} & 1 & 28.4 & 28.6 & 28.8 & 29.2 & 0.2 & Control vs. S12, $P<0.08$ \\
\hline & 2 & 28.4 & 28.2 & 28.0 & 28.7 & 0.2 & \\
\hline & Overall mean & 28.4 & 28.4 & 28.4 & 28.9 & 0.2 & \\
\hline \multirow{2}{*}{ Milk yield, $\mathrm{kg} / \mathrm{d}$} & 1 & 38.4 & 36.8 & 37.3 & 37.5 & 0.6 & \\
\hline & 2 & 37.0 & 35.9 & 36.2 & 37.0 & 0.5 & \\
\hline \multirow{2}{*}{ Fat, $\%$} & 2 & 3.26 & 3.24 & 3.31 & 3.29 & 0.05 & \\
\hline & Overall mean & 3.21 & 3.30 & 3.35 & 3.33 & 0.04 & Control vs. M12, $P<0.06$; control vs. S12, $P<0.11$ \\
\hline \multirow{3}{*}{ Fat, $\mathrm{kg} / \mathrm{d}$} & 1 & 1.21 & 1.24 & 1.26 & 1.26 & 0.03 & \\
\hline & 2 & 1.21 & 1.17 & 1.20 & 1.22 & 0.02 & \\
\hline & Overall mean & 1.21 & 1.21 & 1.23 & 1.24 & 0.02 & \\
\hline True protein, $\%$ & 1 & 2.90 & 3.02 & 3.02 & 2.98 & 0.03 & Control vs. M12, $P<0.10$; control vs. M6, $P<0.13$ \\
\hline True protein, kg/d & Overall mean & 1.10 & 1.09 & 1.11 & 1.12 & 0.02 & \\
\hline \multirow{3}{*}{ Lactose, $\%$} & 1 & 4.50 & 4.58 & 4.59 & 4.58 & 0.05 & \\
\hline & 2 & 4.57 & 4.50 & 4.58 & 4.56 & 0.03 & M6 vs. M12, $P<0.14$ \\
\hline & Overall mean & 4.45 & 4.54 & 4.59 & 4.57 & 0.03 & \\
\hline \multirow[t]{3}{*}{ Lactose, $\mathrm{kg} / \mathrm{d}$} & 1 & 1.73 & 1.69 & 1.72 & 1.72 & 0.04 & \\
\hline & 2 & 1.70 & 1.63 & 1.67 & 1.69 & 0.03 & \\
\hline & Overall mean & 1.71 & 1.66 & 1.69 & 1.70 & 0.02 & \\
\hline \multirow[t]{3}{*}{$\mathrm{TS}, \%$} & 1 & 11.46 & 11.89 & 11.93 & 11.84 & 0.14 & Control vs. M12, $P<0.11$ \\
\hline & 2 & 11.73 & 11.67 & 11.84 & 11.83 & 0.09 & M6 vs. M12, $P<0.14$ \\
\hline & Overall mean & 11.59 & 11.78 & 11.89 & 11.84 & 0.08 & Control vs. M12, $P<0.06$ \\
\hline \multirow{3}{*}{$\mathrm{TS}, \mathrm{kg} / \mathrm{d}$} & 1 & 4.38 & 4.44 & 4.46 & 4.38 & 0.09 & \\
\hline & 2 & 4.36 & 4.20 & 4.30 & 4.37 & 0.07 & \\
\hline & Overall mean & 4.37 & 4.29 & 4.38 & 4.40 & 0.06 & \\
\hline Urea $\mathrm{N}, \mathrm{mg} / \mathrm{dL}$ & 1 & 13.2 & 13.0 & 13.2 & 12.8 & 0.2 & \\
\hline
\end{tabular}

${ }^{1}$ Mepron from Evonik-Degussa Corporation (Kennesaw, GA); Smartamine M from Adisseo USA Inc. (Alpharetta, GA).

supplementation, cows fed M12 tended to have higher TS percentage in milk than control cows at the end of wk 1 (11.93 vs. $11.46 \% ; P<0.11)$ and when assessed as overall means (11.89 vs. $11.59 \% ; P<0.06)$. In addition, cows fed M6 and M12 tended $(P<0.14)$ to have different TS percentages in milk when assessed using wk-2 data only (11.69 vs. $11.84 \%$ ). Differences in TS yield, milk urea $\mathrm{N}$ concentration, and SCC among treatments were not significant at any of the time points measured. Body weight of cows averaged approximately $700 \mathrm{~kg}$ and BCS averaged approximately 2.9 and were similar among treatments.

Results from the carryover analysis for productionrelated variables are described in Table 3 and include the residual means and the differences of residuals for contrasts with $P<0.15$. Evidence of carryover effects was confined mostly to DMI and SCC; effects were not present for milk yield and most other aspects of milk composition.

Results presented in Table 4 describe the predictions from 3 commonly used ration evaluation and formulation models used in the dairy industry. All models predicted that both energy and protein were supplied well in excess of predicted requirements for the cows at the production levels measured in this experiment. In general, the models yielded similar predictions for RDP supply, metabolizable Met supply and balance (where calculated), and ratio of Lys:Met. Metabolizable protein supply as predicted by AminoCow was less than that predicted by the other 2 models, which resulted in 
Table 3. Least squares means for residuals for analysis of carryover effects within Latin square designs for cows fed a control diet (rC) or diets supplemented with $6 \mathrm{~g} / \mathrm{d}$ of rumen-protected Met (RP-Met) from Mepron (rM6), $12 \mathrm{~g} / \mathrm{d}$ from Mepron (rM12), or 12 g/d of RP-Met from Smartamine M $(\mathrm{rS} 12)^{1}$

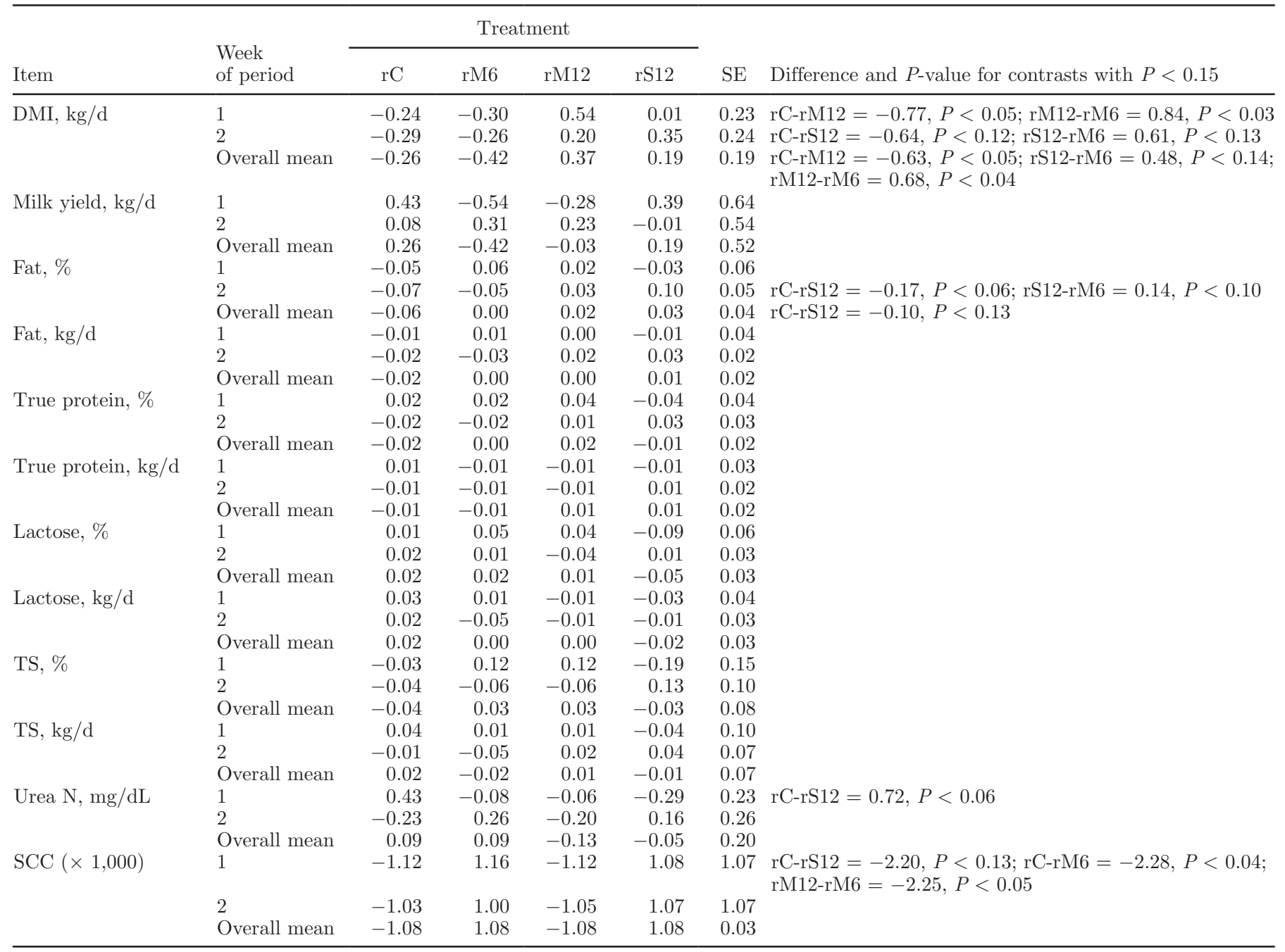

${ }^{1}$ Mepron from Evonik-Degussa Corporation (Kennesaw, GA); Smartamine M from Adisseo USA Inc. (Alpharetta, GA).

higher calculated ratios of Met and Lys in MP in this model.

\section{DISCUSSION}

In this experiment, addition of RP-Met sources to the diet resulted in generally increased percentages of fat and true protein in milk; however, it is interesting to note that the magnitude and statistical significance of these responses differed depending on period length within Latin squares. It is known that postruminal infusion of $\mathrm{CN}$ or AA results in increased milk protein content within $7 \mathrm{~d}$ after infusion (Clark, 1975; Schwab et al., 1976); however, potential implications of the current findings are that researchers should carefully consider their choice of period length when evaluating production responses to AA within Latin squares.
Despite previous results (Bucholtz et al., 2006) that suggested carryover effects to RP-Met supplementation in Latin square designs, carryover effects were largely absent in the current data set. The most prevalent carryover effects and trends for carryover effects were detected during analysis of DMI. It is somewhat difficult to speculate on these potential carryover effects of treatment on DMI and their biological meaning. The DMI was decreased when M12 was fed after the control diet with no added Met during the first experimental week only; S12 resulted in a similar response during the second experimental week, again only if this treatment followed the control. We speculate that this might be linked to the slight sulfur smell of the RP-Met sources. In previous work, Griel et al. (1968) reported lower DMI because of suspected odor effects from a Met analog in some groups of lactating cows. In the present study, 
Table 4. Comparison of model predictions of diets using CPM-Dairy, AminoCow, and the 2001 Dairy NRC model $^{1}$

\begin{tabular}{|c|c|c|c|}
\hline \multirow[b]{2}{*}{ Item } & \multicolumn{3}{|c|}{ Model } \\
\hline & CPM-Dairy & AminoCow & 2001 Dairy NRC \\
\hline \multicolumn{4}{|l|}{ Control } \\
\hline ME allowable milk, $\mathrm{kg} / \mathrm{d}$ & 54.2 & - & - \\
\hline $\mathrm{NE}_{\mathrm{L}}$ balance, Mcal/d & - & +8.1 & +7.9 \\
\hline $\mathrm{NE}_{\mathrm{L}}$ allowable milk, $\mathrm{kg} / \mathrm{d}$ & - & - & 50.0 \\
\hline MP allowable milk, $\mathrm{kg} / \mathrm{d}$ & 51.5 & - & 50.4 \\
\hline MP supply, g/d & 3,300 & 2,579 & 3,203 \\
\hline MP balance, $\mathrm{g} / \mathrm{d}$ & +624 & +860 & +558 \\
\hline Rumen $\mathrm{N}$ balance, $\%$ of requirement & 116 & - & - \\
\hline Predicted RDP, \% & 10.4 & 10.9 & 10.1 \\
\hline Metabolizable Met, g/d & 65 & 58 & 56 \\
\hline Met balance, $\mathrm{g} / \mathrm{d}$ & +16 & +12 & - \\
\hline Met, $\%$ of MP & 1.96 & 2.25 & 1.75 \\
\hline Lys, $\%$ of MP & 6.92 & 8.43 & 6.42 \\
\hline Lys:Met & 3.53 & 3.74 & 3.67 \\
\hline \multicolumn{4}{|l|}{ S12 } \\
\hline ME allowable milk, $\mathrm{kg} / \mathrm{d}$ & 54.4 & - & - \\
\hline $\mathrm{NE}_{\mathrm{L}}$ balance, Mcal/d & - & +9.2 & +8.1 \\
\hline $\mathrm{NE}_{\mathrm{L}}$ allowable milk, $\mathrm{kg} / \mathrm{d}$ & - & - & 49.4 \\
\hline MP allowable milk, $\mathrm{kg} / \mathrm{d}$ & 51.5 & - & 50.4 \\
\hline MP supply, g/d & 3,371 & 2,635 & 3,271 \\
\hline MP balance, $\mathrm{g} / \mathrm{d}$ & +660 & +925 & +593 \\
\hline Rumen $\mathrm{N}$ balance, $\%$ of requirement & 116 & - & - \\
\hline Predicted RDP, \% & 10.4 & 10.4 & 10.1 \\
\hline Metabolizable Met, g/d & 73 & 68 & 63 \\
\hline Met balance, $\mathrm{g} / \mathrm{d}$ & +24 & +22 & - \\
\hline Met, $\%$ of MP & 2.17 & 2.59 & 1.92 \\
\hline Lys, $\%$ of MP & 6.90 & 8.41 & 6.40 \\
\hline Lys:Met & 3.17 & 3.25 & 3.33 \\
\hline \multicolumn{4}{|l|}{ M12 } \\
\hline ME allowable milk, $\mathrm{kg} / \mathrm{d}$ & 53.0 & - & - \\
\hline $\mathrm{NE}_{\mathrm{L}}$ balance, Mcal/d & - & +8.6 & +7.9 \\
\hline $\mathrm{NE}_{\mathrm{L}}$ allowable milk, $\mathrm{kg} / \mathrm{d}$ & - & - & 48.2 \\
\hline MP allowable milk, $\mathrm{kg} / \mathrm{d}$ & 50.0 & - & 49.2 \\
\hline MP supply, g/d & 3,310 & 2,593 & 3,215 \\
\hline MP balance, $\mathrm{g} / \mathrm{d}$ & +634 & +883 & +578 \\
\hline Rumen $\mathrm{N}$ balance, $\%$ of requirement & 116 & - & - \\
\hline Predicted RDP, \% & 10.4 & 10.9 & 10.1 \\
\hline Metabolizable Met, g/d & 72 & 66 & 63 \\
\hline Met balance, $\mathrm{g} / \mathrm{d}$ & +24 & +20 & - \\
\hline Met, $\%$ of MP & 2.19 & 2.53 & 1.97 \\
\hline Lys, $\%$ of MP & 6.90 & 8.42 & 6.41 \\
\hline Lys:Met & 3.15 & 3.32 & 3.25 \\
\hline \multicolumn{4}{|l|}{ M6 } \\
\hline ME allowable milk, $\mathrm{kg} / \mathrm{d}$ & 53.5 & - & - \\
\hline $\mathrm{NE}_{\mathrm{L}}$ balance, $\mathrm{Mcal} / \mathrm{d}$ & - & +8.4 & +8.0 \\
\hline $\mathrm{NE}_{\mathrm{L}}$ allowable milk, $\mathrm{kg} / \mathrm{d}$ & - & - & 48.8 \\
\hline MP allowable milk, $\mathrm{kg} / \mathrm{d}$ & 50.5 & - & 49.5 \\
\hline MP supply, g/d & 3,304 & 2,589 & 3,208 \\
\hline MP balance, $\mathrm{g} / \mathrm{d}$ & +633 & +877 & +570 \\
\hline Rumen $\mathrm{N}$ balance, $\%$ of requirement & 116 & - & - \\
\hline Predicted RDP, $\%$ & 10.4 & 10.9 & 10.1 \\
\hline Metabolizable Met, $\mathrm{g} / \mathrm{d}$ & 69 & 62 & 60 \\
\hline Met balance, $\mathrm{g} / \mathrm{d}$ & +20.0 & +16 & - \\
\hline Met, $\%$ of MP & 2.08 & 2.39 & 1.86 \\
\hline Lys, $\%$ of MP & 6.91 & 8.43 & 6.42 \\
\hline Lys:Met & 3.33 & 3.53 & 3.45 \\
\hline
\end{tabular}

${ }^{1}$ Performance and intake data from overall means used in comparison. Models: CPM-Dairy version 3.0 from University of Pennsylvania, Miner Institute, and Cornell University; AminoCow from Evonik-Degussa Corporation; and the NRC (2001) Dairy model. 
this carryover effect on DMI appeared to be reversed if M6 was fed after either RP-Met source at $12 \mathrm{~g} / \mathrm{d}$. We believe this provides some evidence that dietary adaptation periods in experiments evaluating RP-Met sources should perhaps last longer than $2 \mathrm{wk}$.

In this experiment, feeding RP-Met regardless of source tended to increase milk fat percentage during the first week of treatment and when assessed over the entire treatment period; however, differences in milk fat yield were not significant. Reported effects of Met supplementation on milk fat percentage and yield have been inconsistent. Socha et al. (2008) reported that duodenal infusion of Met increased milk fat percentage and yield in cows during early lactation $(\sim 15 \mathrm{wk}$ of lactation), but not peak ( $\sim 5 \mathrm{wk}$ of lactation) or midlactation ( $\sim 21$ wk of lactation). Misciatteilli et al. (2003) also determined that early-lactation cows fed RP-Met had increased milk fat percentage compared with control cows; however, supplementation did not affect milk fat yield. Overton et al. (1996) reported that RP-Met supplementation during the transition period and early lactation increased yield of $3.5 \%$ FCM during the first $105 \mathrm{~d}$ of lactation. In contrast, several other studies (Leonardi et al., 2003; Noftsger and St-Pierre, 2003; Broderick et al., 2008; Preynat et al., 2009) reported that RP-Met supplementation did not affect milk fat percentage or yield. Specific mechanisms by which Met supplementation may affect milk fat, including ruminal effects (Patton et al., 1968) or postabsorptive effects on lipid metabolism mediated through methyl metabolism (Emmanuel and Kennelly, 1984) or lipoprotein metabolism, remain largely speculative. Nevertheless, results across experiments appear to be quite inconsistent with regard to stage of lactation in terms of whether increased milk fat percentage is accompanied by increased milk fat yield.

As reviewed by the NRC (2001) and generally accepted, Met is the most limiting AA or is colimiting with Lys for milk protein production when cows are fed corn silage and alfalfa diets. Furthermore, the NRC (2001) reported that relationships of both content and yield of milk protein with digestible Met supply, expressed as a percentage of MP, were best described by rectilinear models (straight line at lower digestible Met supplies leading to a breakpoint as digestible Met supply increases). Leonardi et al. (2003) determined that equal amounts of RP-Met increased milk protein percentage for cows fed both high- and low-CP diets, although milk production and milk protein yield were not affected by treatment. Despite the lack of milk protein yield response, they interpreted their results as supportive of the concept of characterizing Met supply by expressing it as a percentage of MP supply. In the present study, supplementation with RP-Met increased milk protein percentage in the first week of the period and when assessed over the entire treatment period, but when evaluated during wk 2 of treatment, there was no effect on milk protein percentage. Patterns of response for milk protein percentage generally were similar between the 2 sources of RP-Met used in this study; however, milk protein yield was not affected by treatment. We believe that there are 3 potential explanations for this. First, our data are consistent with the relationships summarized by the NRC (2001) in which digestible Met supply was more strongly related to milk protein percentage $\left(\mathrm{r}^{2}=0.76\right)$ than with milk protein yield $\left(\mathrm{r}^{2}=\right.$ 0.40 ). This difference could be attributable to biological factors or the potential that generally greater variance in milk yield than milk protein percentage makes it less likely to detect small differences in milk protein yield statistically, especially in experiments with low replication. Second, Socha et al. (2008) reported that midlactation cows (stage of lactation and milk yield similar to cows in the present study) responded to increased Met supply through increased milk protein content without an effect on milk protein yield, whereas cows earlier in lactation and at generally higher production levels than cows in the current study responded to increased Met supply through both increased milk protein content and milk protein yield. This suggests that milk protein synthesis (grams per day) is more responsive to Met supply in higher producing cows than lower producing cows later in lactation. Finally, the modest responses of milk protein percentage to RP-Met supplementation may result from the substantially positive Met balance (grams per day) predicted by both CPM Dairy and AminoCow (Table 4), irrespective of Met supply relative to total MP supply. This suggests that formulation strategies focused solely on Met supply as a percentage of MP without consideration of actual amounts of Met supplied relative to amounts required may lead to less reliable responses of milk protein synthesis to changes in diet formulation.

\section{CONCLUSIONS}

Supplementation of RP-Met in this experiment generally increased percentages of fat and true protein in milk; however, the magnitude and statistical significance of responses varied depending on period length, suggesting that study design and treatment duration may affect the interpretation of production responses to RP-Met. Increasing Met supply to cows increased milk protein percentage, but not milk protein yield, in this experiment, suggesting that actual milk protein synthesis may be less responsive to Met supply in midlactation cows than in higher producing early-lactation cows. Finally, results suggest that potential responses of 
milk protein synthesis to increased Met supply should not be evaluated solely using ratio-based approaches independent of the actual amount of Met supplied.

\section{ACKNOWLEDGMENTS}

The assistance of the following colleagues at Cornell University in implementing the study is gratefully acknowledged: G. Birdsall, W. Jones, R. Axtell, and the rest of the staff at the Cornell University Dairy Teaching and Research Center. We acknowledge the financial support of Evonik-Degussa Corporation in conduct of the research described herein.

\section{REFERENCES}

AOAC. 2000. Official Methods of Analysis. 17th ed. Assoc. Off. Anal. Chem., Arlington, VA.

Berthiaume, R., M. C. Thivierge, R. A. Patton, P. Dubreuil, M. Stevenson, B. W. McBride, and H. Lapierre. 2006. Effect of ruminally protected methionine on splanchic metabolism of amino acids in lactating dairy cows. J. Dairy Sci. 89:1621-1634.

Broderick, G. A., M. J. Stevenson, R. A. Patton, N. E. Lobos, and J. J. Olmos Colmenero. 2008. Effect of supplementing rumen-protected methionine on production and nitrogen excretion in lactating dairy cows. J. Dairy Sci. 91:1092-1102.

Bucholtz, H. F., R. A. Patton, J. S. Liesman, P. N. Naasz, and M. J. Stevenson. 2006. Milk production and carry-over effects of methionine supplements in lactating dairy cows. J. Dairy Sci. 89(Suppl. 1):77. (Abstr.)

Clark, J. H. 1975. Lactational responses to postruminal administration of proteins and amino acids. J. Dairy Sci. 58:1178-1197.

Doepel, L., D. Pacheco, J. J. Kennelly, M. D. Hanigan, I. F. Lopez, and H. Lapierre. 2004. Milk protein synthesis as a function of amino acid supply. J. Dairy Sci. 87:1279-1297.

Dubois, M., K. A. Gilles, J. K. Hamilton, P. A. Rebers, and F. Smith. 1956. Colorimetric method for determination of sugars and related substances. Anal. Chem. 28:350-351.

Emmanuel, B., and J. J. Kennelly. 1984. Kinetics of methionine and choline and their incorporation into plasma lipids and milk components in lactating goats. J. Dairy Sci. 67:1912-1918.

Gill, J. L. 1978. Design and Analysis of Experiments in the Animal and Medical Sciences. The Iowa State University Press, Ames.

Goering, H. K., and P. J. Van Soest. 1970. Forage fiber analysis. USDA-ARS Handbook No. 379. US Government Printing Office, Washington, DC.

Griel, L. C. Jr., R. A. Patton, R. D. McCarthy, and P. T. Chandler. 1968. Milk production response to feeding methionine hydroxyl analog to lactating dairy cows. J. Dairy Sci. 51:1866-1867.

Holm, J., I. Bjorck, A. Drews, and N. G. Asp. 1986. A rapid method for the analysis of starch. Starch/Die Starke 7:224-226.
Krishnamoorthy, U., T. V. Muscato, C. J. Sniffen, and P. J. Van Soest. 1982. Nitrogen fractions in selected feedstuffs. J. Dairy Sci. $65: 217-225$.

Lapierre, H., D. Pacheco, R. Berthiaume, D. R. Ouellet, C. G. Schwab, P. Dubreuil, G. Holtrop, and G. E. Lobley. 2006. What is the true supply of amino acids for a dairy cow? J. Dairy Sci. 89(E Suppl.):E1-E14.

Leonardi, C., M. Stevenson, and L. E. Armentano. 2003. Effect of two levels of crude protein and methione supplementation on performance of dairy cows. J. Dairy Sci. 86:4033-4042.

Misciatteilli, L., V. F. Kristensen, M. Vestergaard, M. R. Welsbjerg, K. Sejrsen, and T. Hvelplund. 2003. Milk production, nutrient utilization, and endocrine responses to increased postruminal lysine and methionine supply in dairy cows. J. Dairy Sci. 86:275-286.

NRC. 2001. Nutrient Requirements of Dairy Cattle. 7 th rev. ed. Natl. Acad. Press, Washington, DC.

Noftsger, S., and N. R. St-Pierre. 2003. Supplementation of methionine and selection of highly digestible rumen undegradable protein to improve nitrogen efficiency for milk production. J. Dairy Sci. 86:958-969.

Overton, T. R., D. W. LaCount, T. M. Cicela, and J. H. Clark. 1996. Evaluation of a ruminally protected methionine product for lactating dairy cows. J. Dairy Sci. 79:631-638.

Papas, A. M., C. J. Sniffen, and T. V. Muscato. 1984. Effectiveness of rumen-protected methionine for delivering methionine postruminally in dairy cows. J. Dairy Sci. 67:545-552.

Patton, R. A., R. D. McCarthy, and L. C. Griel Jr.. 1968. Lipid synthesis by ruminal microorganisms. 1 . Stimulation by methionine in vitro. J. Dairy Sci. 51:1310-1311.

Preynat, A., H. Lapierre, M. C. Thivierge, M. F. Palin, J. J. Matte, A. Desrochers, and C. L. Girard. 2009. Effects of supplements of folic acid, vitamin $\mathrm{B}_{12}$, and rumen-protected methionine on whole body metabolism of methionine and glucose in lactating dairy cows. J. Dairy Sci. 92:677-689.

SAS Institute. 2001. SAS User's Guide: Statistics, Version 8 Edition. SAS Inst. Inc., Cary, NC.

Schwab, C. G., L. D. Satter, and B. Clay. 1976. Response of lactating dairy cows to abomasal infusion of amino acids. J. Dairy Sci. 59:1254-1270.

Smith, K. L., S. E. Stebulis, M. R. Waldron, and T. R. Overton. 2007. Prepartum 2,4-thiazolidinedione alters metabolic dynamics and dry matter intake of dairy cows. J. Dairy Sci. 90:3660-3670.

Socha, M. T., C. G. Schwab, D. E. Putnam, N. L. Whitehouse, B. D. Garthwaite, and G. A. Ducharme. 2008. Extent of methionine limitation in peak-, early-, and mid-lactation dairy cows. J. Dairy Sci. 91:1996-2010.

Van Soest, P. J., J. B. Robertson, and B. A. Lewis. 1991. Methods for dietary fiber, neutral detergent fiber, and nonstarch polysaccharides in relation to animal nutrition. J. Dairy Sci. 74:3583-3597.

Wildman, E. E., G. M. Jones, P. E. Wagner, H. F. Troutt Jr., and T. N. Lesch. 1982. A dairy cow body condition scoring system and its relationship to selected production characteristics. J. Dairy Sci. 65:495-501. 